\title{
Simulating Long-Term Development of Greenhouse Gas Emissions, Plant Biomass, and Soil Moisture of a Temperate Grassland Ecosystem under Elevated Atmospheric $\mathrm{CO}_{2}$
}

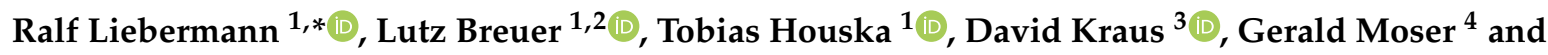 \\ Philipp Kraft ${ }^{1}$ (1) \\ 1 Institute for Landscape Ecology and Resources Management, Research Centre for BioSystems, Land Use and \\ Nutrition (iFZ), Justus Liebig University Giessen, Heinrich-Buff-Ring 26, 35392 Giessen, Germany; \\ lutz.breuer@umwelt.uni-giessen.de (L.B.); tobias.houska@umwelt.uni-giessen.de (T.H.); \\ philipp.kraft@umwelt.uni-giessen.de (P.K.) \\ 2 Center for International Development and Environmental Research, Justus Liebig University Giessen, \\ Senckenbergstraße 3, 35390 Giessen, Germany \\ 3 Institute of Meteorology and Climate Research-Atmospheric Environmental Research (IMK-IFU), \\ Karlsruhe Institute of Technology (KIT), Kreuzeckbahnstraße 19, 82467 Garmisch-Partenkirchen, Germany; \\ david.kraus@kit.edu \\ 4 Institute for Plant Ecology, Research Centre for BioSystems, Land Use and Nutrition (iFZ), Justus Liebig \\ University Giessen, Heinrich-Buff-Ring 26, 35392 Giessen, Germany; gerald.moser@bio.uni-giessen.de \\ * Correspondence: ralf.liebermann@umwelt.uni-giessen.de; Tel.: +49-641-99-37398
}

Received: 18 November 2019; Accepted: 26 December 2019; Published: 29 December 2019

check for updates

\begin{abstract}
The rising atmospheric $\mathrm{CO}_{2}$ concentrations have effects on the worldwide ecosystems such as an increase in biomass production as well as changing soil processes and conditions. Since this affects the ecosystem's net balance of greenhouse gas emissions, reliable projections about the $\mathrm{CO}_{2}$ impact are required. Deterministic models can capture the interrelated biological, hydrological, and biogeochemical processes under changing $\mathrm{CO}_{2}$ concentrations if long-term observations for model testing are provided. We used 13 years of data on above-ground biomass production, soil moisture, and emissions of $\mathrm{CO}_{2}$ and $\mathrm{N}_{2} \mathrm{O}$ from the Free Air Carbon dioxide Enrichment (FACE) grassland experiment in Giessen, Germany. Then, the LandscapeDNDC ecosystem model was calibrated with data measured under current $\mathrm{CO}_{2}$ concentrations and validated under elevated $\mathrm{CO}_{2}$. Depending on the hydrological conditions, different $\mathrm{CO}_{2}$ effects were observed and captured well for all ecosystem variables but $\mathrm{N}_{2} \mathrm{O}$ emissions. Confidence intervals of ensemble simulations covered up to $96 \%$ of measured biomass and $\mathrm{CO}_{2}$ emission values, while soil water content was well simulated in terms of annual cycle and location-specific $\mathrm{CO}_{2}$ effects. $\mathrm{N}_{2} \mathrm{O}$ emissions under elevated $\mathrm{CO}_{2}$ could not be reproduced, presumably due to a rarely considered mineralization process of organic nitrogen, which is not yet included in LandscapeDNDC.
\end{abstract}

Keywords: FACE; grassland; biogeochemical ecosystem model; soil moisture; greenhouse gas emissions; plant biomass

\section{Introduction}

To date, biogeochemical cycles all over the world are undergoing fundamental adjustments as a response to rising atmospheric greenhouse gas (GHG) concentrations and related climatic and plant physiological consequences [1]. Especially carbon dioxide $\left(\mathrm{CO}_{2}\right)$ has received widespread attention due to its role in the global radiation budget, making its increasing concentrations the main driver for 
climatic changes such as rising temperatures, shifting precipitation patterns, and unpredictable extreme events [2]. To assess the interaction of elevated $\mathrm{CO}_{2}$ with the carbon (C) cycle outside of controlled laboratory environments, Free Air Carbon dioxide Enrichment (FACE) experiments were established to observe the reaction of whole ecosystems to enhanced $\mathrm{CO}_{2}$ levels. During these FACE experiments, elevated $\mathrm{CO}_{2}$ was found to fertilize plant primary production, leading, for example, to yield increases for cereals [3] and grapevine [4] as well as increased litter production in forests [5]. Due to the usually short duration of FACE experiments, it remains unclear whether these effects are permanent. Nutrients such as nitrogen $(\mathrm{N})$, for example, have been hypothesized to become progressively limited in relation to increased $\mathrm{C}$ input via $\mathrm{CO}_{2}$ fertilization [6]. Reliable predictions are made difficult both by a lack of process understanding of the $\mathrm{C}-\mathrm{N}$ interactions [7] and by the low general validity of hypotheses on the effect of increased $\mathrm{CO}_{2}$ [8]. Process-based ecosystem models used for hypothesis testing are therefore required to include a range of effects, e.g., on decomposition by soil bacteria [9], soil respiration and root biomass [10], root exudation [11], and root-associated mycorrhizal fungi [12].

However, translating these processes into a reliable projection of the ecosystem response to enhanced $\mathrm{CO}_{2}$ by means of a set of mathematical equations is challenging. The various approaches include models that concentrate, for example, on the factors directly relevant to greenhouse gas emissions [13-15] or track the dependencies for the entire ecosystem (see, for example, the LPJ model family $[16,17])$. Such ecosystem models are predestined for mapping the manifold effects of elevated $\mathrm{CO}_{2}$ concentrations but require correspondingly long observation series from FACE experiments for validation $[18,19]$. In a comprehensive study, several complex ecosystem models were calibrated and tested against measurements from two Forest-FACE experiments $[20,21]$ showing that all models lacked the capability to simulate long-term effects of enhanced $\mathrm{CO}_{2}$ adequately. The authors argue that shortcomings of the model simulations are connected to deficits either in the representation of the $\mathrm{N}$ cycle or its link to the $\mathrm{C}$ cycle $[20,22,23]$. Especially the model examination at ambient $\mathrm{CO}_{2}[22]$ showed how fallibilities of the $\mathrm{CO}_{2}$ reaction can be deduced a priori from inconsistencies in the combined cycles of carbon, nitrogen, and water.

For this study, we utilized 13 years of observation data from the grassland FACE experiment in Giessen (Germany), which has already been used for several simulation studies [24-26]. By employing the process-based ecosystem model LandscapeDNDC [27], simulations were calibrated against observations collected at ambient $\mathrm{CO}_{2}$ concentrations and validated with measurements collected at elevated atmospheric $\mathrm{CO}_{2}$ concentrations. Multivariate ensemble simulations of biomass production, soil moisture, and greenhouse gas emissions were evaluated with special attention to the interactions between the cycles of $\mathrm{C}, \mathrm{N}$, and water. The aim of this study is to find out whether process-based models such as LandscapeDNDC can be used to adequately simulate the long-term behavior of an ecosystem under increased atmospheric $\mathrm{CO}_{2}$ concentrations.

\section{Materials and Methods}

\subsection{Study Site}

The investigated temperate, permanent grassland is part of the "Environmental Monitoring and Climate Impact Research Station Linden” near Giessen, Germany (50 $32^{\prime}$ N, $8^{\circ} 41.3^{\prime}$ E, $172 \mathrm{~m}$ a.s.l.). Local climatic conditions are characterized by annual precipitation of $563 \mathrm{~mm}$ and an average air temperature of $9.5^{\circ} \mathrm{C}$ in the period from April 1995 to December 2011. The grassland was cultivated while the soil remained undisturbed for over 100 years and was not irrigated during the investigated period. The vegetation has been described as an Arrhenatheretum elatioris Br.-Bl. Filipendula ulmaria sub-community with up to 35 different plant species dominated by tall oat grass, yellow oat grass, meadow soft grass, meadow geranium, and white beadstraw on a stagnofluvic gleysol on loamy-sandy sediments over clay [28]. The top soil layers (A-horizon $0-12 \mathrm{~cm}$ ) show a partially low bulk density (0.63-1.01 $\mathrm{g} \mathrm{cm}^{-3}$ ), which, however, increases rapidly with soil depth (up to $1.52 \mathrm{~g} \mathrm{~cm}^{-3}$ at $15 \mathrm{~cm}$, 
see [29]). The grassland has been managed extensively with mineral fertilizer application (ammonium nitrate, $\mathrm{NH}_{4} \mathrm{NO}_{3}$ ) of $40 \mathrm{~kg} \mathrm{ha}^{-1} \mathrm{yr}^{-1}$ in mid-April and two cuts per year.

The grassland research area was established in 1993/94, and in May 1998, the Giessen Free Air Carbon dioxide Enrichment (GiFACE) experiment started to investigate the effects of rising atmospheric $\mathrm{CO}_{2}$ concentrations [29]. We used data collected from a total of six plots, each surrounded by a fumigation ring. The three plots E1, E2, and E3 were fumigated with additional $\mathrm{CO}_{2}$ (=elevated $\mathrm{CO}_{2}, \mathrm{eCO}_{2}$ ), while the remaining three plots $\mathrm{A} 1, \mathrm{~A} 2$, and $\mathrm{A} 3$ were not fumigated for control purposes (=ambient $\mathrm{CO}_{2}, \mathrm{aCO}_{2}$ ). The experiment is designed in such a way that the fumigation is dynamically adjusted to about $20 \%$ above the ambient concentration. In reality, the average $\mathrm{CO}_{2}$ concentrations were 22.3\% higher for E1-E3 (annual means: 458 ppm in 1999 up to $484 \mathrm{ppm}$ in 2011) compared to A1-A3 (386 ppm/401 ppm) in the evaluation period. The evaluation period started in August 1998 with the onset of $\mathrm{CO}_{2}$ emission measurements and ended in December 2011. In addition, data about weather conditions (global radiation, air temperature, relative humidity, precipitation), $\mathrm{N}$ deposition, groundwater level and nitrate $\left(\mathrm{NO}_{3}\right)$ concentrations, vertically resolved soil properties (texture, bulk density, pH, organic $\mathrm{C}$ and $\mathrm{N}$ content), soil water content (SWC, measured at soil depth $0-15 \mathrm{~cm}$ with TDR (time domain reflectometry) probes [30]), plant harvest (aboveground biomass, $\mathrm{C} / \mathrm{N}$ ratio, cutting schedule), and $\mathrm{CO}_{2}$ and nitrous oxide $\left(\mathrm{N}_{2} \mathrm{O}\right)$ emissions (both measured at dusk) are used for this study. Emissions were measured with opaque static chambers placed on permanently installed frames (10 cm deep) and analyzed on a gas chromatograph (for details, see [31]). Since the opacity impedes photosynthesis related carbon fluxes during emission measurements, we considered the measured $\mathrm{CO}_{2}$ emissions to be total ecosystem respiration minus growth respiration.

The plots were paired in three blocks A1/E1, A2/E2, and A3/E3 with different hydrological characteristics. We described the plots according to their respective average groundwater levels (agl) as driest $(\mathrm{A} 1 / \mathrm{E} 1, \mathrm{agl}=-1.02 \mathrm{~m})$, medium $(\mathrm{A} 3 / \mathrm{E} 3, \mathrm{agl}=-0.76 \mathrm{~m})$, and wettest $(\mathrm{A} 2 / \mathrm{E} 2, \mathrm{agl}=-0.66 \mathrm{~m})$ pairs. Groundwater is generally shallow and highly variable in this area, rising close to the surface in most winter periods. A slight north facing slope (ca. $2 \%$ ) indicates potential lateral inflow of groundwater from the upslope croplands. Regular measurement of groundwater $\mathrm{NO}_{3}{ }^{-}$concentrations was started in 2016 with several measurements per month at seven different points on the test site, with the exception of January. No such data are available for the observation period of this study. Hence, the annual cycle from 2016 was used, interpolated and averaged over all seven measuring points of the test site as a proxy.

More about relevant measurement data can be found at http://www.face2face.center (last access on 11 November 2019) and Table A1.

\subsection{Data Implementation}

All measured data used for model simulations (see Table A1) are classified according to four different categories: model initialization, model forcing data, model calibration data, and model parameters. Initialization uses data to set up initial values of organic $C$ and $N$ content of the soil at the beginning of the simulation. Forcing data determine the boundary conditions of the simulation. They include management events (cutting, fertilizer application), weather data, $\mathrm{N}$ deposition, atmospheric $\mathrm{CO}_{2}$ concentrations, groundwater $\mathrm{NO}_{3}{ }^{-}$concentrations, and groundwater levels (interpolated to daily time resolution). Calibration data are measured data belonging to five target variables that are used for sensitivity analysis, calibration, and/or validation. They include harvested plant biomass, plant $\mathrm{C}-\mathrm{N}$ ratio (only sensitivity analysis and calibration), SWC, and emissions of $\mathrm{CO}_{2}$ and $\mathrm{N}_{2} \mathrm{O}$. Parameters are ecosystem properties whose values are either fixed or calibrated within predefined ranges. Fixed parameters were derived from literature (soil texture, $\mathrm{pH}$, and bulk density). Calibrated parameters include only soil hydraulic properties (field capacity, wilting point, hydraulic conductivity, vanGenuchten $\alpha$ and $\mathrm{n}$ ) whose ranges were derived from literature (field capacity, wilting point), expert knowledge $(\alpha, n)$, and ad hoc infiltration experiments (sks).

It should be noted that the behavioral simulations were performed for both $\mathrm{aCO}_{2}$ and $\mathrm{eCO}_{2}$ with a steeper gradient in saturated hydraulic conductivity sks in the uppermost soil layers. The gradient 
corresponds to sks values obtained during recent ad hoc infiltration measurements, which were ignored only during the sensitivity analysis to prevent unintended false positive selection of sks as a sensitive parameter. Ranges to calibrate field capacity and wilting point for each of the three blocks A1/E1, $\mathrm{A} 2 / \mathrm{E} 2$, and A3/E3 were derived from water retention curves (see [32]).

\subsection{Model Setup}

LandscapeDNDC $[27,33]$ is an ecosystem model framework that provides an exchangeable pool of submodels for the description of various compartments. We selected canopyECM [34], PlaMo ${ }^{\mathrm{x}}, \mathrm{MeTr}^{\mathrm{x}}$, and EcHy according to their suitability with regard to the $\mathrm{CO}_{2}$ effect. PlaMo ${ }^{\mathrm{x}}$ [35] is based on the Farquhar model [36] and is used for plant physiology and photosynthesis, which allows the simulation of the $\mathrm{CO}_{2}$ effect on biomass production. $\mathrm{MeTr}^{\mathrm{x}}$ [37] was selected to model the biogeochemistry, making it possible to simulate the (indirect) effect of $\mathrm{eCO}_{2}$ on soil microbiology and associated greenhouse gas emissions. EcHy ([38], under review) was implemented to simulate both hydrology and its relationship to plant development, making ecohydrological effects of $\mathrm{eCO}_{2}$ on soil water content visible. $\mathrm{MeTr}$ and EcHy were supplemented by additional algorithms that simulate the influence of groundwater, including $\mathrm{NO}_{3}{ }^{-}$dissolved in groundwater, on soil hydrology and chemistry [26].

The runtime of the simulations began in April 1995, whereby the three years before the start of the evaluation period in August 1998 were used as spin-up. All submodels ran consecutively with a two-hourly resolution. Since we considered a grassland ecosystem on a plot scale, we used a laterally homogeneous LandscapeDNDC setup. Vertical resolution was set to $50 \mathrm{~mm}$ for the upper soil layers $(0-20 \mathrm{~cm})$, increasing to $150-200 \mathrm{~mm}$ for the lower layers $(50-100 \mathrm{~cm})$. While the layers were different in respect of their respective soil properties, each layer was divided into several sublayers sharing the same characteristics.

\subsection{Sensitivity Analysis and Calibration}

The LandscapeDNDC setup we used contains a subset of more than 100 indefinite parameters, i.e., parameters whose values are uncertain within limits chosen by expert knowledge and literature. For these parameters, a set of values had to be estimated to give the best possible agreement between simulation and measurement data under $\mathrm{aCO}_{2}$. In this context, $\mathrm{aCO}_{2}$ measurement data were used exclusively for calibration, while validation was based only on $\mathrm{eCO}_{2}$ data. The agreement was quantified by using Root Mean Squared Error (RMSE) as a target function.

As the number of necessary model runs grows exponentially with the number of parameters, a sensitivity analysis was performed at the beginning to reduce the number of parameters to the most sensitive. We used the Fourier Amplitude Sensitivity Test (FAST, see $[39,40]$ ) to determine the most sensitive parameters under $\mathrm{aCO}_{2}$ conditions on the basis of 250,000 simulations each (for details, see Figure A1 and Table A2).

For the remaining sensitive parameters $(n=16), 250,000$ parameter sets for A1, A2, and A3 were calculated and simulated again using Latin Hypercube Sampling (LHS, see [41]), while all other parameters were left at their initial values. From the simulations generated by LHS, a selection of the "best" (which we call behavioral from here on) simulations based on General Likelihood Uncertainty Estimation (GLUE, see [42]) was made. GLUE allows the calibration of LandscapeDNDC to an ensemble of suitable (that is, behavioral) simulations that meet previously defined threshold objective function criteria (see Houska et al. [24]). These thresholds were chosen as upper limits for the RMSE of the behavioral simulations, meaning that each behavioral simulation must have an RMSE for each target variable less than or equal to the set value. Starting with the values by Houska et al., a further lowering was carried out, during which the subsequent threshold values (Table 1) were determined by simultaneous manual adjustment at all target variables and $\mathrm{aCO}_{2}$ plots. 
Table 1. Maximum acceptable Root Mean Squared Error (RMSE) for the target variables during model calibration.

\begin{tabular}{cccc}
\hline Target Variables & Threshold & Unit & Evaluated for Plots \\
\hline Plant Biomass & 1300 & $\mathrm{~kg} \mathrm{DW} \mathrm{ha}^{-1}$ & \\
C-N ratio & 4.10 & - & \\
$\mathrm{CO}_{2}$ emissions & 200 & $\mathrm{mg} \mathrm{CO}_{2} \mathrm{~m}^{-2} \mathrm{~h}^{-1}$ & $\mathrm{~A} 1, \mathrm{~A} 2, \mathrm{~A} 3$ \\
$\mathrm{~N}_{2} \mathrm{O}$ emissions & 26.0 & $\mu \mathrm{g} \mathrm{N}_{2} \mathrm{O}-\mathrm{N} \mathrm{m}^{-2} \mathrm{~h}^{-1}$ & \\
Soil Water Content (SWC) & 9.0 & vol.- $\%$ & \\
\hline
\end{tabular}

These simulations selected as behavioral under $\mathrm{aCO}_{2}$ were then repeated for validation under $\mathrm{eCO}_{2}$ while retaining the associated parameter sets. Only the input values for atmospheric $\mathrm{CO}_{2}$ concentrations and soil properties were replaced by the measured values of the $\mathrm{eCO}_{2}$ plots. The free open source software SPOTPY (Statistical Parameter Optimization Tool for Python, [43]) was used for all sensitivity analyses and calibration runs.

\subsection{Evaluation}

For the assessment of the $\mathrm{CO}_{2}$ effect in the ensemble simulations, it had to be determined to what extent such an effect could also be proven in observation data. Statistical tests were performed to determine whether significant differences between $\mathrm{aCO}_{2}$ and $\mathrm{eCO}_{2}$ were present in the respective measurement data. Since the measurements were not normally distributed, we chose the nonparametric Mann-Whitney U-test to assess the probability of whether the data from $\mathrm{aCO}_{2}$ and $\mathrm{eCO}_{2}$ plots could belong to the same distribution.

The model ensembles of the behavioral simulations both for $\mathrm{aCO}_{2}$ and $\mathrm{eCO}_{2}$ were summarized as cumulative diagrams (except SWC) and compared with the measured data. The ensemble simulations were aggregated into confidence intervals with a confidence coefficient of $95 \%$. For a better quantitative evaluation, the RMSE values of the behavioral (non-cumulative) simulations for $\mathrm{aCO}_{2}$ and $\mathrm{eCO}_{2}$ (see Table A3) were averaged and compared. Non-cumulative measured data were used for statistical significance tests (see Table A4) and assessed on a significance level of $\alpha=0.05$.

\section{Results}

We evaluated the target variables of plant biomass, $\mathrm{SWC}, \mathrm{CO}_{2}$, and $\mathrm{N}_{2} \mathrm{O}$ emissions. The plant $\mathrm{C} / \mathrm{N}$ ratio was only used for calibration and is therefore not evaluated in detail here. Average values of the simulated $\mathrm{C} / \mathrm{N}$ ratios were between 24.7 and 27.6, which is about the same range as the average measured values (25.0-28.3).

\subsection{Cumulative Plant Biomass}

Limits of the confidence intervals increased from $\mathrm{aCO}_{2}$ to $\mathrm{eCO}_{2}$ for all blocks, including almost all (96\%) cumulative measured biomass values for A2, E2, A3, and E3 (Figure 1). However, significantly increased biomass due to $\mathrm{eCO}_{2}$ was only measured for the driest block (A1/E1, see Tables A4 and A5) but not for the wetter blocks (A2/E2 and A3/E3). For block A1/E1, percentage of cumulative measured values within the confidence intervals remained stable (37\%/41\%), even though average RMSE increased moderately $\left(+18 \%\right.$, Table A3) under $\mathrm{eCO}_{2}$. Since all measured values of $\mathrm{A} 1$ and $\mathrm{E} 1$ were close to the upper edge of their respective confidence intervals, a slight underestimation by the simulations remained at this block both for $\mathrm{aCO}_{2}$ and $\mathrm{eCO}_{2}$. 

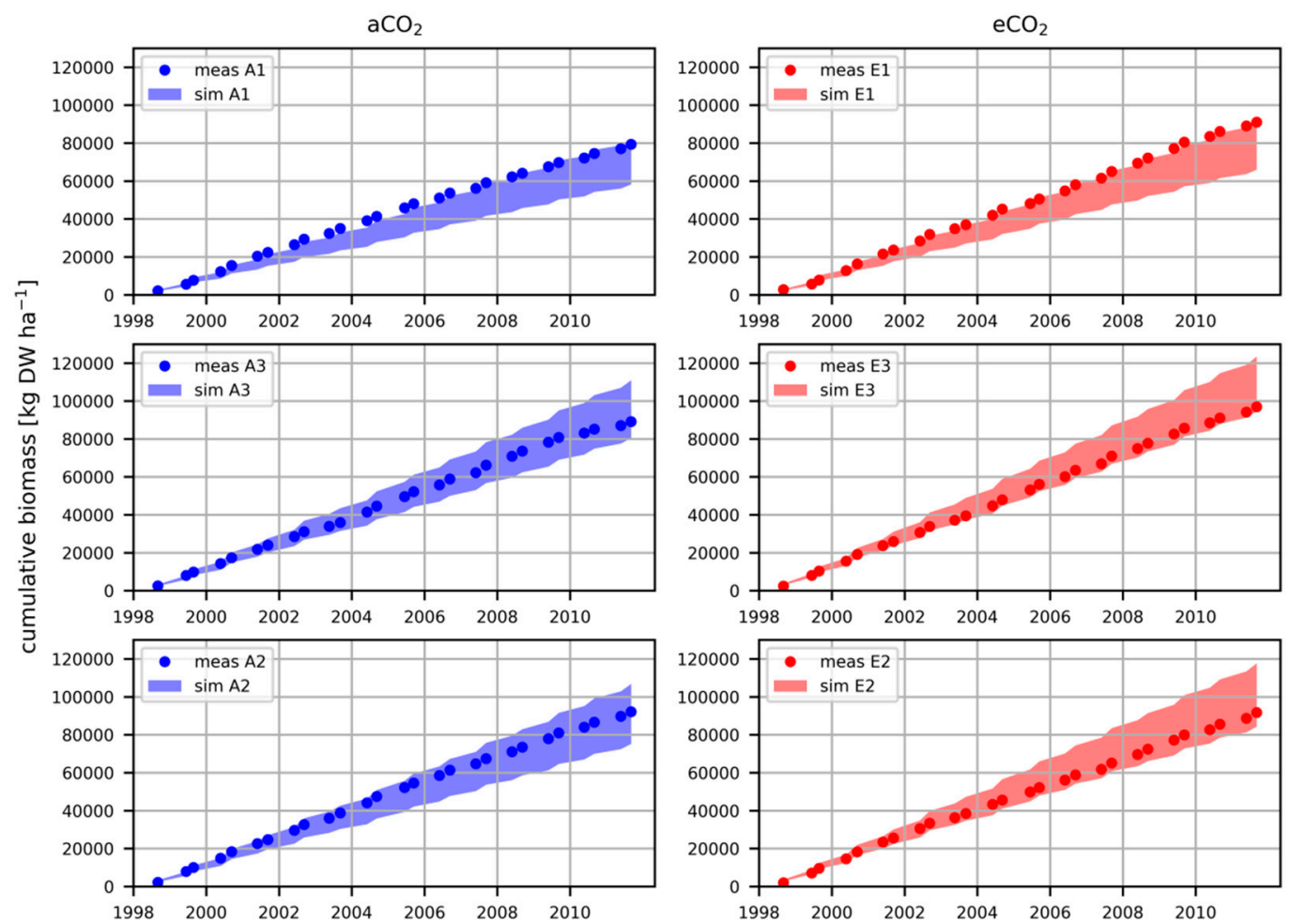

Figure 1. Cumulative measured and simulated values of harvested plant biomass for ambient $\left(\mathrm{aCO}_{2}\right)$ and elevated $\mathrm{CO}_{2}\left(\mathrm{eCO}_{2}\right)$ Free Air Carbon dioxide Enrichment (FACE) rings. Plots are arranged according to increasing soil moisture from driest (top, A1/E1) to medium (middle, A3/E3) and wettest (bottom, A2/E2) rings. Measurements are depicted in dots; confidence intervals of simulations are depicted as colored areas.

\subsection{Soil Water Content}

The simulations generally followed the dynamics of the observations, though the confidence intervals did not include the majority of the measured SWC values (see Figure 2). Short-term fluctuations of the SWC as well as drying phases were well captured by the simulations. Longer periods in which the soil was saturated were primarily seen in the winter months. This occurred in the simulations as well as in the measurements but at a higher level for the latter, which is why peak values of the SWC in these periods were often underestimated. This applied to both $\mathrm{aCO}_{2}$ and $\mathrm{eCO}_{2}$, even though the measurement curves diverged strongly in some cases, with SWC being up to twice as high under $\mathrm{eCO}_{2}$ as under $\mathrm{aCO}_{2}$.

The reaction of the measured SWC to elevated $\mathrm{CO}_{2}$ varied between the plots; based on average values, the SWC increased significantly (Tables $\mathrm{A} 4$ and $\mathrm{A} 5)$ under $\mathrm{eCO}_{2}$ at $\mathrm{A} 1 / \mathrm{E} 1(+3.6$ vol.- $\%$, on average) and at A3/E3 (+1.1 vol.-\%). However, at block A2/E2, SWC also decreased significantly under $\mathrm{eCO}_{2}(-2.3$ vol.- $\%)$. Confidence intervals showed a qualitatively similar $\mathrm{eCO}_{2}$ reaction as the simulated SWC increased from A1 to E1 but decreased from A2 to E2. Furthermore, average RMSE (Table A3) was consistently lower during validation (E1-E3) than during calibration (A1-A3). 

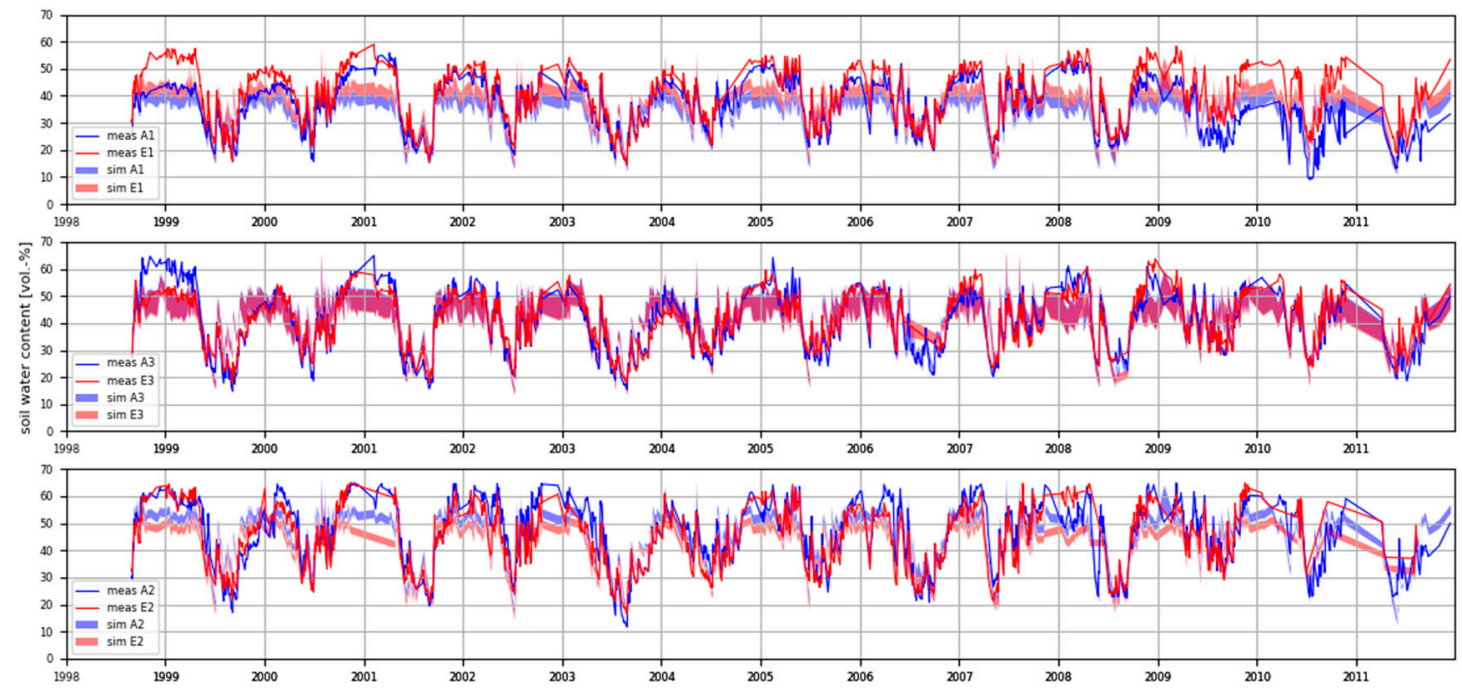

Figure 2. Time series of soil water content in $0-15 \mathrm{~cm}$ soil depths from ambient $\left(\mathrm{aCO}_{2}\right)$ and elevated $\mathrm{CO}_{2}\left(\mathrm{eCO}_{2}\right)$ FACE rings. Plots are arranged according to increasing soil moisture from driest (top, $\mathrm{A} 1 / \mathrm{E} 1$ ) to medium (middle, A3/E3) and wettest (bottom, A2/E2) rings. Measurements are depicted in lines, and confidence intervals of simulations are depicted as colored areas.

\subsection{Cumulative $\mathrm{CO}_{2}$ Emissions}

As can be seen in Figure 3, measured and simulated $\mathrm{CO}_{2}$ emissions were higher in all blocks under $\mathrm{eCO}_{2}$ than under $\mathrm{aCO}_{2}$. The increase was significant for $\mathrm{A} 1 / \mathrm{E} 1$ and $\mathrm{A} 3 / \mathrm{E} 3$ but not for $\mathrm{A} 2 / \mathrm{E} 2$ (Tables A4 and $\mathrm{A} 5$ ). Confidence intervals included fewer cumulative measured values under $\mathrm{eCO}_{2}$ than under $\mathrm{aCO}_{2}$ treatment. The proportions ranged from $94 \%$ to $44 \%$ at block $\mathrm{A} 1 / \mathrm{E} 1$, from $79 \%$ to $65 \%$ at $\mathrm{A} 2 / \mathrm{E} 2$, and from $70 \%$ to $69 \%$ at A3/E3. Outliers almost exclusively occurred before 2004, with the exception of $\mathrm{E} 1$, where the confidence interval was below the measurements until 2007. For both $\mathrm{aCO}_{2}$ and $\mathrm{eCO}_{2}$, all outliers were close to the upper edge of the confidence range, indicating an underestimation of LandscapeDNDC during the first half of the simulation period. No deviations occurred after 2007. Average RMSE values increased under $\mathrm{eCO}_{2}$, with a moderate increase from A1 to E1 (about 20\%) and a slight increase from A3 to E3 (about 9\%). However, RMSE (Table A3) at E2 remained virtually unchanged compared to A2 (increase of about $1 \%$ ).
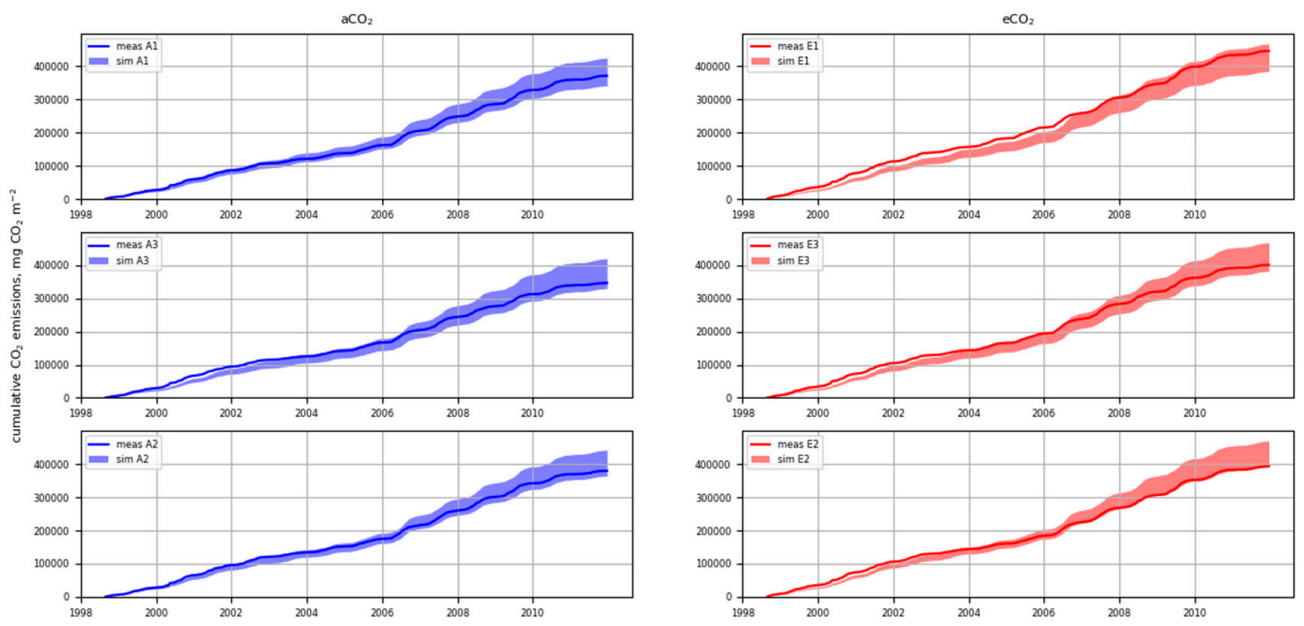

Figure 3. Cumulative measured and simulated $\mathrm{CO}_{2}$ emissions from ambient $\left(\mathrm{aCO}_{2}\right)$ and elevated $\mathrm{CO}_{2}$ $\left(\mathrm{eCO}_{2}\right)$ FACE rings. Plots are arranged according to increasing soil moisture from driest (top, A1/E1) to medium (middle, A3/E3) and wettest (bottom, A2/E2) rings. Measurements are depicted in lines, and confidence intervals of simulations are depicted as colored areas. 


\subsection{Cumulative $\mathrm{N}_{2} \mathrm{O}$ Emissions}

The measured $\mathrm{N}_{2} \mathrm{O}$ emissions for $\mathrm{eCO}_{2}$ increased significantly compared to $\mathrm{aCO}_{2}$ at all blocks (Table A4), while the associated confidence intervals of the LandscapeDNDC simulations remained largely unchanged (Figure 4). For $\mathrm{aCO}_{2}$ plots, confidence intervals included 39.2\% (A1), 27.8\% (A2), and 38.3\% (A3) of the cumulative measured $\mathrm{N}_{2} \mathrm{O}$ emissions, thereby underestimating the measurements, especially in the early years up to 2007/08. A very contrasting picture appeared for $\mathrm{eCO}_{2}$, where confidence intervals were completely underestimating measurements, including none of the cumulative measured values for E1, E2, and E3. The extent of the underestimation depended strongly on the plot under consideration. If we compared the last cumulative values of measurements and the upper limit of the confidence intervals, we found a relative deviation of only $9 \%$ for E2 but of $282 \%$ for E1. For E1 in particular, a sequence of several sudden increases in cumulative $\mathrm{N}_{2} \mathrm{O}$ emissions in the years 1998-2001 could be observed. Consequently, the RMSE (Table A3) of $\mathrm{N}_{2} \mathrm{O}$ emissions increased for all eCO $\mathrm{Cl}_{2}$ plots but much more for E1 (+190\% compared to A1) than for E2 (+28\%) and E3 (+57\%).
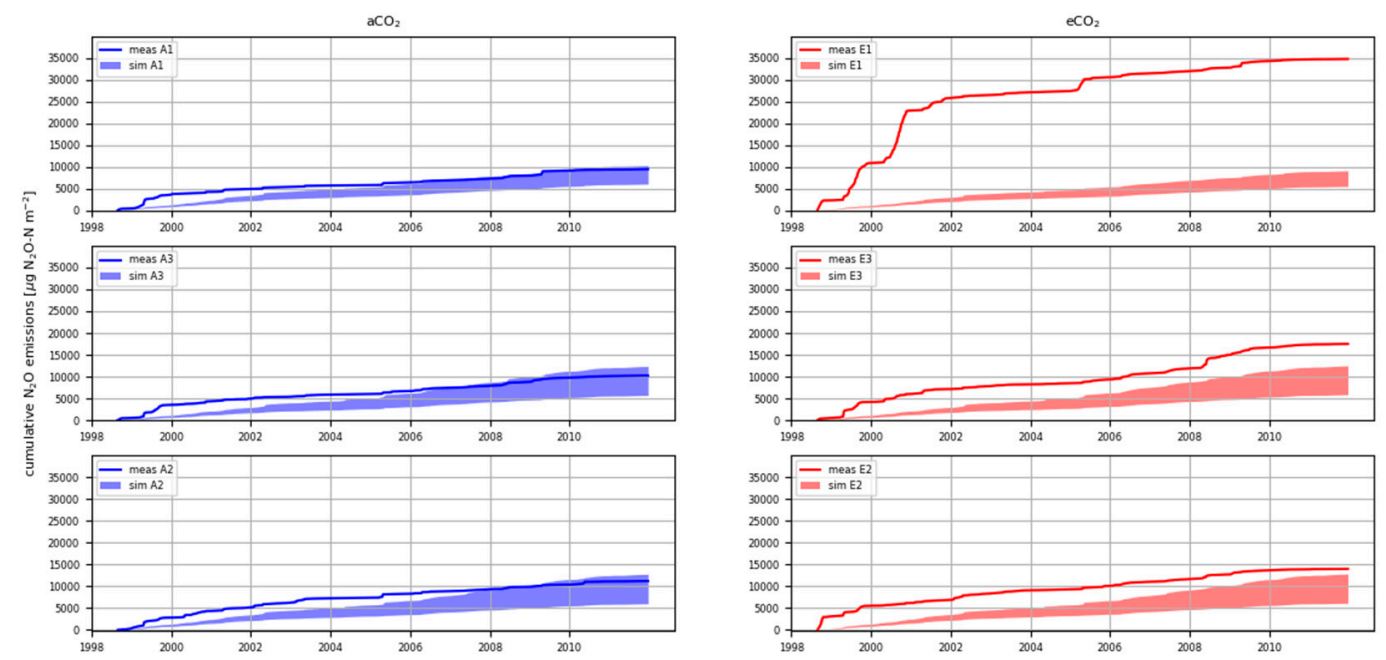

Figure 4. Cumulative measured and simulated $\mathrm{N}_{2} \mathrm{O}$ emissions from ambient $\left(\mathrm{aCO}_{2}\right)$ and elevated $\mathrm{CO}_{2}$ $\left(\mathrm{eCO}_{2}\right)$ FACE rings. Plots are arranged according to increasing soil moisture from driest (top, A1/E1) to medium (middle, A3/E3) and wettest (bottom, A2/E2) rings. Measurements are depicted in lines, and confidence intervals of simulations are depicted as colored areas.

\section{Discussion}

The study presented here aimed at simulating long-term effects of atmospheric $\mathrm{CO}_{2}$ enrichment on various environmental target variables of a grassland ecosystem. The $\mathrm{CO}_{2}$ fumigation was performed as part of a long-term FACE experiment, from which the measured data of plant biomass, $\mathrm{SWC}, \mathrm{CO}_{2}$, and $\mathrm{N}_{2} \mathrm{O}$ emissions collected continuously for more than 13 years were taken and used for calibration and validation. With the exception of $\mathrm{N}_{2} \mathrm{O}$ emissions, it was possible to satisfactorily simulate the long-term effects of the $\mathrm{CO}_{2}$ enrichment for all target variables.

\subsection{Biomass}

Agreement between simulation and measurement of biomass, especially with regard to the $\mathrm{eCO}_{2}$ effect, varied depending on the location. For block A1/E1, agreement with measured values remained essentially the same, suggesting that the $\mathrm{eCO}_{2}$-induced increase in biomass production was correctly simulated by the model, although biomass production itself was slightly underestimated. The opposite was observed for A2/E2, where the agreement between confidence intervals and measured values was almost perfect for both A2 and E2, although the simulations showed an increase due to elevated CO not given by the data. In context, this indicated (at least) two growth factors that were not correctly 
captured in the LandscapeDNDC setup used. One of these factors strengthened the $\mathrm{CO}_{2}$-independent growth for A1/E1, while the other factor negated the $\mathrm{CO}_{2}$ growth effect for A2/E2.

The $\mathrm{eCO}_{2}$ reaction of the biomass differentiated according to the blocks could thus be assumed to be closely related to the respective soil hydrological conditions, which were very different for A1/E1 and A2/E2 with regard to both the mean groundwater levels and the SWC values. Previous research by Andresen et al. [44] found significant correlations of biomass with respect to $\mathrm{CO}_{2}$ treatment and SWC on this study site, explicitly leaving open whether, in this case, a higher biomass was caused by higher SWC or vice versa. Kellner et al. [25] used a coupled hydrological plant model with physics-based soil hydraulics and performed multivariate simulations over the same period as this study. They obtained a RMSE of $1400-1500 \mathrm{~kg} \mathrm{DM} \mathrm{ha}^{-1}$ (dry matter per hectare), which is higher than the corresponding RMSE values in this study (1000-1250 $\left.\mathrm{kg} \mathrm{DM} \mathrm{ha}^{-1}\right)$. We argue that this was due to a major difference in the model setups, since Kellner et al. did not incorporate a possible $\mathrm{N}$ limitation for plant growth. This assumption is backed up by a previous study using an $\mathrm{N}$-limited model approach, which found a massive drop in simulated biomass production if $\mathrm{N}$ uptake from the groundwater was ignored [26]. The same process of $\mathrm{N}$ uptake was also used in this study, showing that biomass production at the field site depends on groundwater-borne $\mathrm{N}$ supply, reflecting more $\mathrm{N}$ limited conditions at the driest block A1/E1 compared to the wettest block A2/E2.

\subsection{SWC}

Agreement between SWC simulations and measurements was satisfactory in terms of RMSE (6.2-7.6\%), which is comparable to results by Kellner et al. [25] who achieved an RMSE of 6-10\% using a physically-based hydrological modeling framework for the same period and field site. The confidence intervals of the simulations did not capture most of the observations but were much narrower than the fluctuation range of the measurement data. Furthermore, simulated SWC values followed the dynamic development of the observed SWC for both the annual cycle and most of the short term fluctuations. The recurrent underestimation of observed SWC peaks in winter was presumably due to the lower saturation level in the simulations, although it is not possible to clearly state to what extent this was due to the model setup or measurement errors (e.g., measured SWC values were partly higher than the pore volume and had to be cut off). Despite this, simulations captured the mean effect of $\mathrm{CO}_{2}$ fumigation and were qualitatively correct at all blocks, even though measured SWC at A1/E1 and $\mathrm{A} 2 / \mathrm{E} 2$ showed opposite $\mathrm{eCO}_{2}$ reactions, while at $\mathrm{A} 3 / \mathrm{E} 3$, almost no change occurred on average.

The reason that the $\mathrm{eCO}_{2}$ effect turned from an increase at the driest plot $\mathrm{E} 1$ to a decrease at the wettest plot E2 could have been the more frequent exceedances of field capacity at E2. Niklaus et al. [45] found a similar increase of the SWC under elevated $\mathrm{CO}_{2}$ in a grassland experiment until the effect was reversed when the field capacity was exceeded. Qi et al. [46] reported reduced transpiration and increased SWC in both simulations and observations when investigating the effect of $\mathrm{eCO}_{2}$ on a semi-arid rangeland.

\subsection{Cumulative $\mathrm{CO}_{2}$ Emissions}

The confidence intervals of the simulated cumulative $\mathrm{CO}_{2}$ emissions generally covered the measured values well (RMSE of $199-239 \mathrm{mg} \mathrm{CO}_{2} \mathrm{~m}^{-2} \mathrm{~h}^{-1}$ ). Only in the first years, the measured $\mathrm{CO}_{2}$ emissions were partially underestimated, especially under $\mathrm{eCO}_{2}$. Since the difference between measured data and simulations built up, especially in the years 1998-2001, we suspected an initial adaptation effect to $\mathrm{CO}_{2}$ fumigation as a possible cause. This agrees with results reported by Kammann [47], who showed that there was an increase in ecosystem respiration in the first two years under $\mathrm{eCO}_{2}$ but that it declined again in the third year. Kammann deduced that a likely cause of increased respiration was either increased rhizodeposition or increased fine root turnover.

However, even long after the initialization of the experiment (e.g., in summer 2010), emission peaks occurred that were underestimated by simulations (see Figure A2), indicating that acclimatization 
to $\mathrm{eCO}_{2}$ is an ongoing process and single weather events, e.g., drying and rewetting, can mask the $\mathrm{CO}_{2}$ effect [48].

\subsection{Cumulative $\mathrm{N}_{2} \mathrm{O}$ Emissions}

The underestimation of the observed $\mathrm{N}_{2} \mathrm{O}$ emissions by the simulation suggested that essential processes of $\mathrm{N}_{2} \mathrm{O}$ formation were not correctly mapped in the model setup used. The regular underestimation of the SWC in winter, for example, could have led to an underestimation of anaerobic denitrification. However, since almost all $\mathrm{N}_{2} \mathrm{O}$ peaks occurred at times outside winter when SWC was not underestimated, shortcomings in peak SWC simulation could not be mainly responsible for the underestimation of $\mathrm{N}_{2} \mathrm{O}$ emissions (see Figures 2 and A3). This would be consistent with the previous assumption that saturated soil conditions are present in periods of high SWC, leading to complete anaerobic denitrification to $\mathrm{N}_{2}$ instead of $\mathrm{N}_{2} \mathrm{O} . \mathrm{N}_{2} \mathrm{O}$ emission peaks during periods of lower SWC that may still arise from denitrification but do not necessarily require anaerobic conditions in the GiFACE meadow soil [49]. In principle, there is also the possibility that $\mathrm{N}_{2} \mathrm{O}$ emissions resulted from the time-delayed aerobic denitrification of $\mathrm{NO}_{3}$, which reached the root zone as a result of high groundwater levels or capillary rise.

Since $\mathrm{N}_{2} \mathrm{O}$ emissions were highest under $\mathrm{eCO}_{2}$ at the driest $\mathrm{A} 1 \mathrm{plot}$, the question arises as to why aerobic denitrification was strongest at the plot with the lowest presumed $\mathrm{NO}_{3}$ supply. An explanation could be that increased $\mathrm{N}_{2} \mathrm{O}$ emissions arose from nitrite $\left(\mathrm{NO}_{2}{ }^{-}\right)$, as suggested by a recently published study by Moser et al. [50] on the field site. Moser et al. conducted a ${ }^{15} \mathrm{~N}$ tracing experiment, suggesting that about $90 \%$ of the additional $\mathrm{N}_{2} \mathrm{O}$ emitted under $\mathrm{eCO}_{2}$ originates from soil organic $\mathrm{N}$, which is first oxidized to $\mathrm{NO}_{2}{ }^{-}$and subsequently reduced to $\mathrm{N}_{2} \mathrm{O}$. The trigger for this could be a priming effect that, in the early years of $\mathrm{CO}_{2}$ fumigation, resulted in increased turnover of soil organic matter (SOM). Root exudation [50] and fine root degradation [51] were already assumed as organic $\mathrm{N}$ sources for increased $\mathrm{N}_{2} \mathrm{O}$ emissions under $\mathrm{eCO}_{2}$ and are possibly related to increased turnover processes due to fungal activity [31,51-53].

It should be noted that neither priming effects nor fungal decomposition processes or even oxidation of organic $\mathrm{N}$ are currently implemented in LandscapeDNDC. If one or more of these processes is substantially involved in $\mathrm{N}_{2} \mathrm{O}$ production in GiFACE, this could explain the underestimation of $\mathrm{N}_{2} \mathrm{O}$ emissions under $\mathrm{eCO}_{2}$.

\section{Conclusions}

The simulations under $\mathrm{aCO}_{2}$ showed a satisfactory agreement with measurements for all target variables, while under $\mathrm{eCO}_{2}$, this could be achieved for biomass, $\mathrm{SWC}$, and $\mathrm{CO}_{2}$ emissions but not for $\mathrm{N}_{2} \mathrm{O}$ emissions. The underlying problem is that $\mathrm{N}_{2} \mathrm{O}$ emissions result from a large number of processes and factors that cannot be monitored at the ecosystem level or only for very short time frames. The consequence of this is that $\mathrm{N}_{2} \mathrm{O}$ emission peaks are often the result of several possible causes, not all of which are necessarily known. In our case, conclusions can be drawn from the interplay of earlier investigations, long-term measurements, and simulations.

The increase in harvest biomass and $\mathrm{CO}_{2}$ emissions under $\mathrm{eCO}_{2}$ speaks for increased production of SOM and soil respiration. Although the increase in respiration could be attributed in part to the increased SWC under $\mathrm{eCO}_{2}$, this did not apply to A2/E2. Here, emissions increased for both $\mathrm{CO}_{2}$ and $\mathrm{N}_{2} \mathrm{O}$ despite generally lower SWC at E2. This suggests that the measured increase in greenhouse gas emissions was largely due to the oxidation of SOM. If this was the case, it can be assumed that $\mathrm{NO}_{3}$ from groundwater is also a rather indirect contributor to the increase in $\mathrm{N}_{2} \mathrm{O}$ emissions. $\mathrm{N}_{2} \mathrm{O}$ production could thus be explained less by anaerobic denitrification of (groundwater) $\mathrm{NO}_{3}$ than by oxidation of labile SOM, the formation of which is forced by the combination of increased $\mathrm{CO}_{2}$ and groundwater $\mathrm{NO}_{3}$. Since LandscapeDNDC is currently unable to capture this, and the simulation quality of the $\mathrm{N}_{2} \mathrm{O}$ emissions under $\mathrm{eCO}_{2}$ differs radically from that of the other target variables, we consider the above explanation approach to be promising. 
The example of $\mathrm{N}_{2} \mathrm{O}$ emissions shows that the assessment of the complex impacts of increased $\mathrm{CO}_{2}$ benefits from the inclusion of several interrelated environmental variables. However, this also implies that weak points in the simulation, e.g., peak SWC values, can impair the simulation quality of the other target variables and must be catered to. For the further use of LandscapeDNDC in groundwater-impacted meadows, we therefore recommend the oxidation of labile organic $\mathrm{N}$ to be included in the next model setup. The same applies to a better implementation of the special hydrological conditions in GiFACE. In this regard, we also recommend further studies on the influence of long-term changes in groundwater levels and nitrate concentrations in groundwater. Finally, research on the mineralization of organic material by mycorrhiza could help to improve projections about greenhouse gas emissions for grasslands under future atmospheric $\mathrm{CO}_{2}$ conditions.

Author Contributions: Conceptualization, L.B. and P.K.; methodology, R.L., T.H. and D.K.; software, R.L., T.H. and D.K.; validation, R.L.; formal analysis, R.L.; investigation, R.L.; data curation, G.M.; writing-original draft preparation, R.L.; writing-review and editing, R.L., P.K., L.B., D.K., G.M. and T.H.; visualization, R.L.; supervision, L.B. and P.K.; project administration, L.B.; funding acquisition, L.B. All authors have read and agreed to the published version of the manuscript.

Funding: We are grateful for long-term financial support of the Hessian Agency for Nature Conservation, Environment and Geology (HLNUG), which allowed the long-term investigations in the Giessen FACE and the contribution of many colleagues of the Institute of Plant Ecology to this dataset. Part of this work was funded by the LOEWE excellence cluster FACE2FACE of the Hessen State Ministry of Higher Education, Research and the Arts. We would like to further acknowledge the financial support provided by the Deutsche Forschungsgemeinschaft (DFG) (BR2238/13-1 and HO6420/1-1).

Acknowledgments: The authors thank their colleagues for continuous support and discussion.

Conflicts of Interest: The authors declare no conflict of interest. The founding sponsors had no role in the design of the study; in the collection, analyses, or interpretation of data; in the writing of the manuscript, and in the decision to publish the results.

\section{Appendix A}

Table A1. Measured data implemented in LandscapeDNDC: FSM = field site measurements (see Section 2.1); $\mathrm{WD}=$ weather data [54]; variable = soil moisture, $\mathrm{CO}_{2}$ and $\mathrm{N}_{2} \mathrm{O}$ emissions measurements ranged from several per week to several per month.

\begin{tabular}{|c|c|c|c|c|c|}
\hline Name & Value/Unit & Start/End & $\begin{array}{c}\text { Temporal } \\
\text { Resolution }\end{array}$ & Usage & Source \\
\hline Air temperature (mean, $\min , \max$ ) & ${ }^{\circ} \mathrm{C}$ & $1995 / 2011$ & daily & Driver data & WD \\
\hline Global radiation & $\mathrm{W} \mathrm{m} \mathrm{m}^{-2}$ & $1995 / 2011$ & daily & Driver data & WD \\
\hline Precipitation & $m m$ day $^{-1}$ & $1995 / 2011$ & daily & Driver data & WD \\
\hline Relative humidity & $\%$ & $1995 / 2011$ & daily & Driver data & WD \\
\hline Groundwater level & $\mathrm{m}$ & $1995 / 2011$ & daily $* 1$ & Driver data & FSM \\
\hline Fertilizer application (ammonium nitrate) & $40 \mathrm{~kg} \mathrm{~N} \mathrm{ha}^{-1} \mathrm{yr}^{-1}$ & $1995 / 2011$ & yearly & Driver data & [31] \\
\hline $\mathrm{N}$ deposition & $14 \mathrm{~kg} \mathrm{~N} \mathrm{ha}^{-1} \mathrm{yr}^{-1}$ & $1993 / 1995$ & mean & Driver data & [55] \\
\hline Field capacity & $\mathrm{mm} \mathrm{m}^{-1}$ & - & - & $\begin{array}{l}\text { Calibrated } \\
\text { parameter }\end{array}$ & [32] \\
\hline Wilting point & $\mathrm{mm} \mathrm{m}^{-1}$ & - & - & $\begin{array}{l}\text { Calibrated } \\
\text { parameter }\end{array}$ & [32] \\
\hline Van Genuchten $\alpha$ & $\mathrm{cm}^{-1}$ & - & - & $\begin{array}{l}\text { Calibrated } \\
\text { parameter }\end{array}$ & [32] \\
\hline Van Genuchten n & - & - & - & $\begin{array}{l}\text { Calibrated } \\
\text { parameter }\end{array}$ & [32] \\
\hline Hydraulic Conductivity & $\mathrm{cm} \min ^{-1}$ & 2017 & - & $\begin{array}{l}\text { Calibrated } \\
\text { parameter }\end{array}$ & FSM \\
\hline Fraction of soil org. $\mathrm{N}$ & $0.08-0.37 \%$ & $2001 / 2002$ & - & Initialization & [29] \\
\hline Fraction of soil org. C & $0.69-3.96 \%$ & $2001 / 2002$ & - & Initialization & [29] \\
\hline Soil pH & $5.4-6.0$ & - & - & Fixed parameter & [29] \\
\hline Cutting height & $4 \mathrm{~cm}$ & - & constant & Fixed parameter & FSM \\
\hline Bulk density profile & $0.63-1.66 \mathrm{~g} \mathrm{~cm}^{-3}$ & - & - & Fixed parameter & {$[29,32]$} \\
\hline Texture (clay, silt, sand) & - & - & constant & Fixed parameter & [32] \\
\hline $\mathrm{CO}_{2}$ concentration & ppm & $1998 / 2011$ & daily & Fixed parameter & FSM \\
\hline Groundwater $\mathrm{NO}_{3}{ }^{-}$concentration & $0.05-23.32 \mathrm{mg} \mathrm{L}^{-1}$ & 2016 & daily & Fixed parameter & FSM \\
\hline
\end{tabular}


Table A1. Cont.

\begin{tabular}{cccccc}
\hline Name & Value/Unit & Start/End & $\begin{array}{c}\text { Temporal } \\
\text { Resolution }\end{array}$ & Usage & Source \\
\hline Plant C-N ratio & - & $1998 / 2011$ & 2 cuts/year & Calibration data & FSM \\
Biomass & $\mathrm{kg} \mathrm{ha}^{-1} \mathrm{yr}^{-1}$ & $1998 / 2011$ & 2 cuts/year & Calibration data & FSM \\
Soil water content & vol.- $\%^{-1}$ & $1998 / 2011$ & variable 2 & Calibration data & FSM \\
$\mathrm{CO}_{2}$ emissions & $\mathrm{mg} \mathrm{CO}_{2} \mathrm{~m}^{-2} \mathrm{~h}^{-1}$ & $1998 / 2011$ & variable & Calibration data & $\mathrm{FSM}$ \\
$\mathrm{N}_{2} \mathrm{O}$ emissions & $\mu \mathrm{g} \mathrm{N} \mathrm{m}^{-2} \mathrm{~h}^{-1}$ & $1998 / 2011$ & variable & Calibration data & FSM \\
\hline
\end{tabular}

$* 1$ = groundwater levels have been recorded several times a week; missing values were linearly interpolated to provide daily data for model initialization; ${ }^{* 2}=$ soil moisture data have been recorded several times per week, and removed of values that either (a) have been measured on days with air temperature below $0{ }^{\circ} \mathrm{C}$, including the two subsequent days, or (b) exceeded the pore volume of the soil.

Table A2. Most sensitive LandscapeDNDC parameters. From left: parameters associated module, internal LandscapeDNDC parameter name, initial value, lower and upper limits of the parameter range, process-related description.

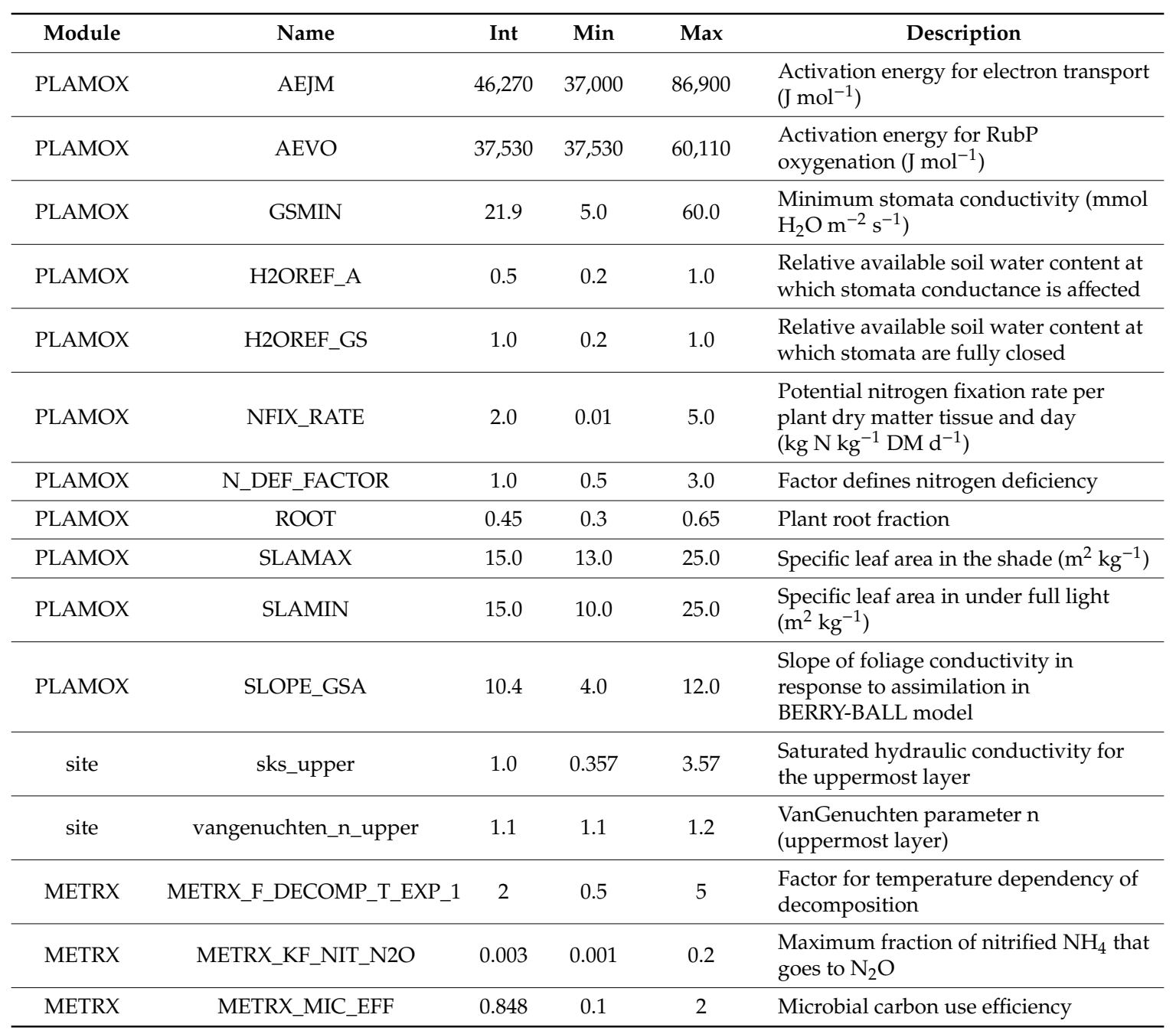

Table A3. Average RMSE of the behavioral simulation runs.

\begin{tabular}{ccccccc}
\hline Target Value & A1 & E1 & A2 & E2 & A3 & E3 \\
\hline Biomass $\left(\mathrm{kg} \mathrm{DW} \mathrm{ha}^{-1}\right)$ & 1056 & 1242 & 1017 & 1076 & 1114 & 1010 \\
$\mathrm{CO}_{2}\left(\mathrm{mg} \mathrm{CO}_{2} \mathrm{~m}^{-2} \mathrm{~h}^{-1}\right)$ & 199.3 & 238.9 & 206.0 & 208.8 & 212.22 & 231.6 \\
$\mathrm{~N}_{2} \mathrm{O}\left(\mu \mathrm{g} \mathrm{N} \mathrm{O}_{2} \mathrm{~N} \mathrm{~m} \mathrm{~m}^{-2} \mathrm{~h}^{-1}\right)$ & 23.85 & 69.12 & 25.71 & 32.83 & 21.71 & 34.00 \\
SWC $(\%)$ & 6.90 & 6.65 & 7.61 & 6.76 & 6.83 & 6.26 \\
\hline
\end{tabular}


Table A4. $p$-Values (Mann-Whitney U Test) of $\mathrm{aCO}_{2} / \mathrm{eCO}_{2}$ measurements.

\begin{tabular}{cccc}
\hline Target Value & A1/E1 & A2/E2 & A3/E3 \\
\hline Biomass & 0.0433 & 0.431 & 0.110 \\
$\mathrm{CO}_{2}$ emissions & $3.992 \times 10^{-9}$ & 0.0692 & 0.000293 \\
$\mathrm{~N}_{2} \mathrm{O}$ emissions & $8.946 \times 10^{-48}$ & 0.00240 & $1.536 \times 10^{-22}$ \\
SWC & $1.255 \times 10^{-32}$ & $2.671 \times 10^{-8}$ & 0.00138 \\
\hline
\end{tabular}

Table A5. Measurement averages and number of measured data points per plot.

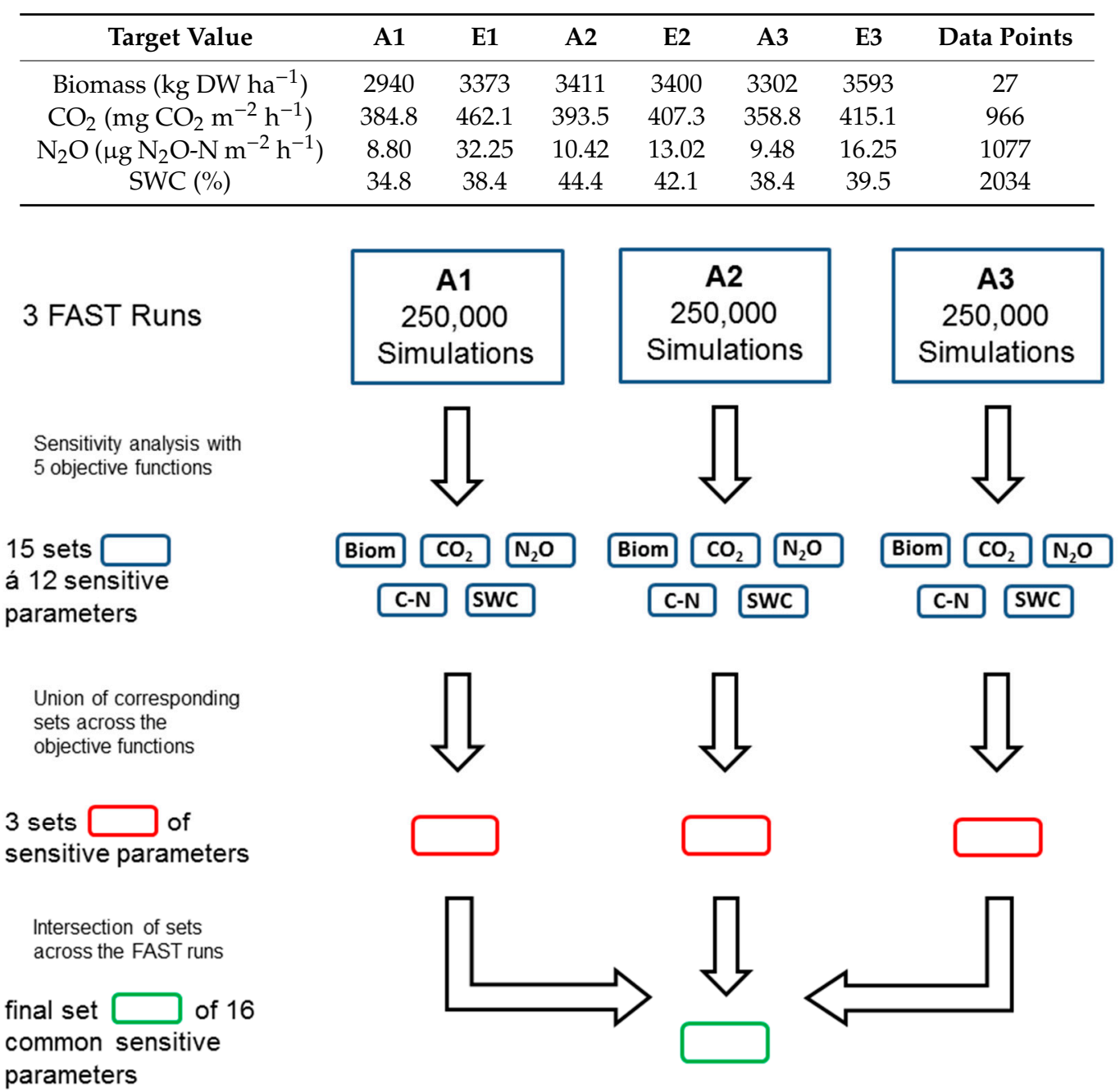

Figure A1. Sensitivity analysis diagram: calculation of the most sensitive parameters where 750,000 parameter sets were sampled in 3 FAST runs, one for each plot (= measuring site). For each run, the 12 most sensitive parameters were calculated separately for 5 objective functions: RMSE of biomass, $\mathrm{C}-\mathrm{N}$ ratio, $\mathrm{CO}_{2}$ emissions, $\mathrm{N}_{2} \mathrm{O}$ emissions, and soil water content. After that, the sensitive parameters were unified within each FAST run. Finally, an intersection of the unified parameters was made among the FAST runs, creating the choice of sensitive parameters that was used for calibration. 


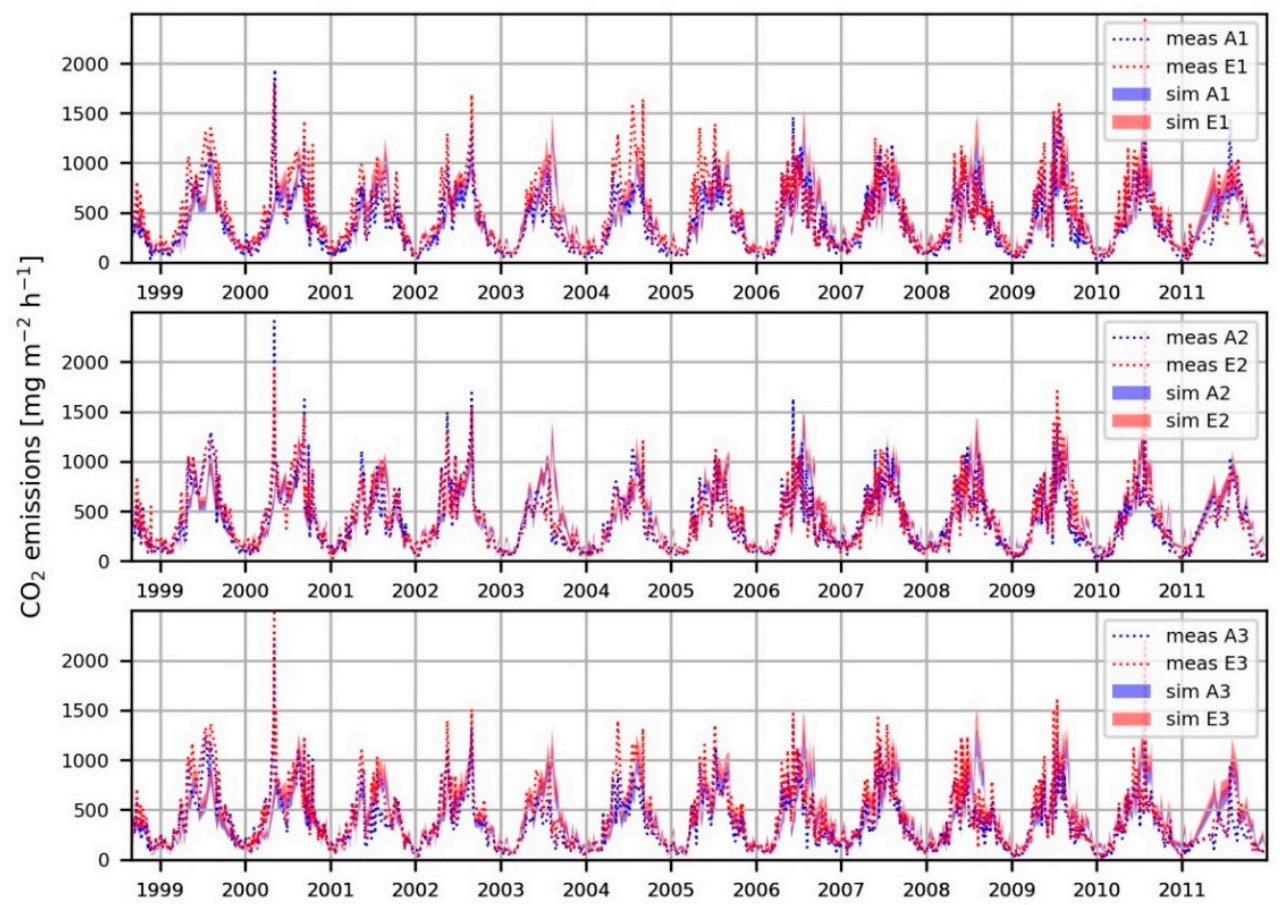

Figure A2. Time series of $\mathrm{CO}_{2}$ emissions. Measurements are depicted in lines, and confidence intervals of simulations are depicted as colored areas.

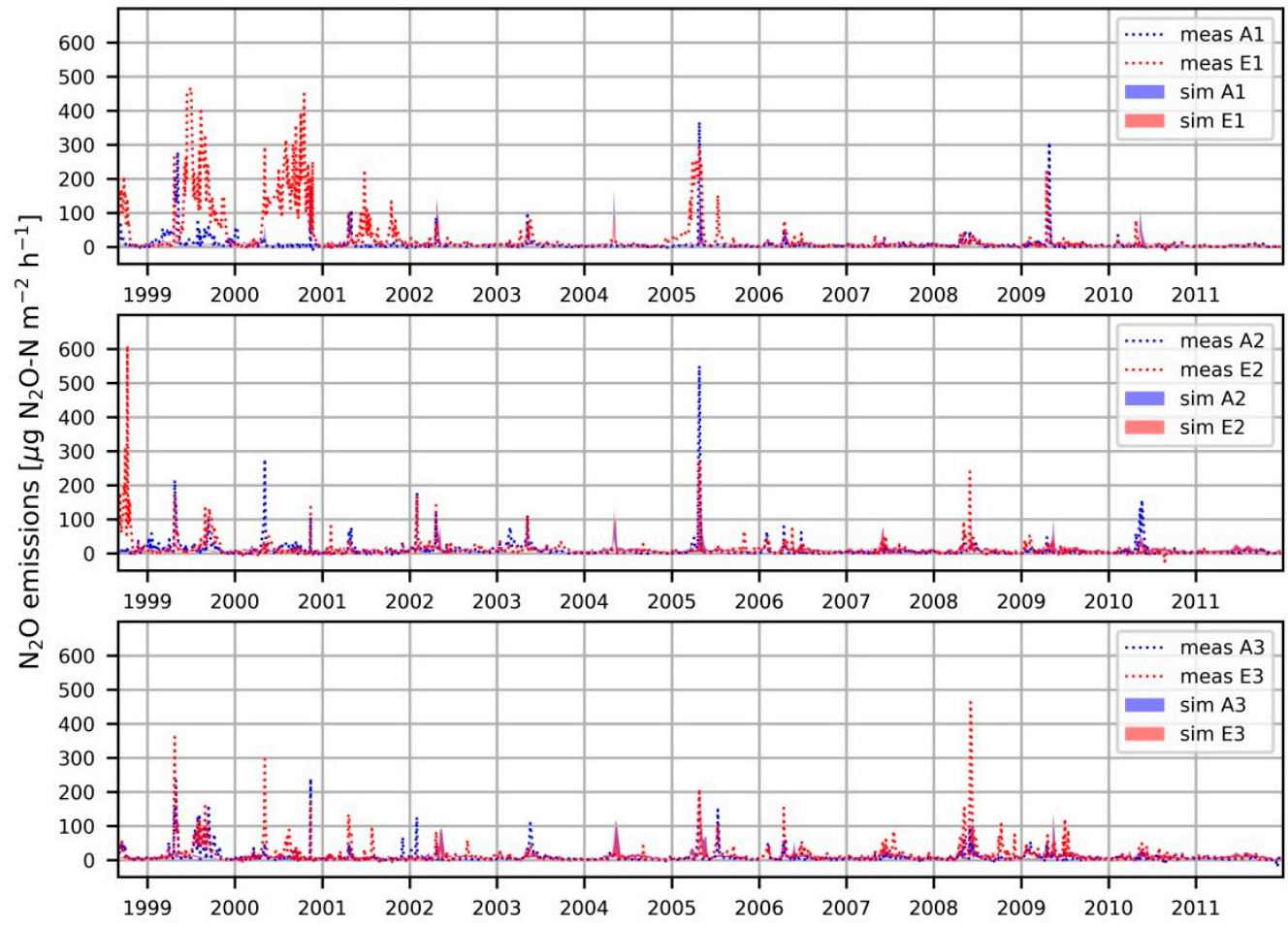

Figure A3. Time series of $\mathrm{N}_{2} \mathrm{O}$ emissions. Measurements are depicted in lines, and confidence intervals of simulations are depicted as colored areas.

\section{References}

1. World Meteorological Organization. The State of Greenhouse Gases in the Atmosphere Based on Global Observations through 2017; WMO: Geneva, Switzerland, 2018. 
2. Reichstein, M.; Bahn, M.; Ciais, P.; Frank, D.; Mahecha, M.D.; Seneviratne, S.I.; Zscheischler, J.; Beer, C.; Buchmann, N.; Frank, D.C.; et al. Climate extremes and the carbon cycle. Nature 2013, 500, 287-295. [CrossRef] [PubMed]

3. Weigel, H.-J.; Manderscheid, R. Crop growth responses to free air $\mathrm{CO}_{2}$ enrichment and nitrogen fertilization: Rotating barley, ryegrass, sugar beet and wheat. Eur. J. Agron. 2012, 43, 97-107. [CrossRef]

4. Bindi, M.; Fibbi, L.; Miglietta, F. Free Air $\mathrm{CO}_{2}$ Enrichment (FACE) of grapevine (Vitis vinifera L.): II. Growth and quality of grape and wine in response to elevated $\mathrm{CO}_{2}$ concentrations. Eur. J. Agron. 2001, 14, 145-155. [CrossRef]

5. Zak, D.R.; Holmes, W.E.; Finzi, A.C.; Norby, R.J.; Schlesinger, W.H. Soil Nitrogen Cycling Under Elevated $\mathrm{Co}_{2}$ : A Synthesis of Forest Face Experiments. Ecol. Appl. 2003, 13, 1508-1514. [CrossRef]

6. Luo, Y.; Su, B.; Currie, W.S.; Dukes, J.S.; Finzi, A.C.; Hartwig, U.; Hungate, B.; McMurtrie, R.E.; Oren, R.; Parton, W.J.; et al. Progressive nitrogen limitation of ecosystem responses to rising atmospheric carbon dioxide. Bioscience 2004, 54, 731-739. [CrossRef]

7. Gärdenäs, A.I.; Ågren, G.I.; Bird, J.A.; Clarholm, M.; Hallin, S.; Ineson, P.; Kätterer, T.; Knicker, H.; Nilsson, S.I.; Näsholm, T.; et al. Knowledge gaps in soil carbon and nitrogen interactions-From molecular to global scale. Soil Biol. Biochem. 2011, 43, 702-717. [CrossRef]

8. $\quad$ Feng, Z.; Rütting, T.; Pleijel, H.; Wallin, G.; Reich, P.B.; Kammann, C.I.; Newton, P.C.D.; Kobayashi, K.; Luo, Y.; Uddling, J. Constraints to nitrogen acquisition of terrestrial plants under elevated $\mathrm{CO}_{2}$. Glob. Chang. Biol. 2015, 21, 3152-3168. [CrossRef]

9. Van Groenigen, K.J.; Qi, X.; Osenberg, C.W.; Luo, Y.; Hungate, B.A. Faster Decomposition Under Increased Atmospheric $\mathrm{CO}_{2}$ Limits Soil Carbon Storage. Science 2014, 344, 508-509. [CrossRef]

10. Cheng, W.; Johnson, D.W. Elevated $\mathrm{CO}_{2}$, rhizosphere processes, and soil organic matter decomposition. Plant Soil 1998, 202, 167-174. [CrossRef]

11. Phillips, D.A.; Fox, T.C.; Six, J. Root exudation (net efflux of amino acids) may increase rhizodeposition under elevated $\mathrm{CO}_{2}$. Glob. Chang. Biol. 2006, 12, 561-567. [CrossRef]

12. Terrer, C.; Vicca, S.; Hungate, B.A.; Phillips, R.P.; Prentice, I.C. Mycorrhizal association as a primary control of the $\mathrm{CO}_{2}$ fertilization effect. Science 2016, 353, 72-74. [CrossRef]

13. Müller, C.; Sherlock, R.R.; Williams, P.H. Mechanistic model for nitrous oxide emission via nitrification and denitrification. Biol. Fertil. Soils 1997, 24, 231-238. [CrossRef]

14. Ryan, M.; Müller, C.; Di, H.J.; Cameron, K.C. The use of artificial neural networks (ANNs) to simulate $\mathrm{N}_{2} \mathrm{O}$ emissions from a temperate grassland ecosystem. Ecol. Model. 2004, 175, 189-194. [CrossRef]

15. Zhang, X.; Niu, G.-Y.; Elshall, A.S.; Ye, M.; Barron-Gafford, G.A.; Pavao-Zuckerman, M. Assessing five evolving microbial enzyme models against field measurements from a semiarid savannah-What are the mechanisms of soil respiration pulses? Geophys. Res. Lett. 2014, 41, 6428-6434. [CrossRef]

16. Sitch, S.; Smith, B.; Prentice, I.C.; Arneth, A.; Bondeau, A.; Cramer, W.; Kaplan, J.O.; Levis, S.; Lucht, W.; Sykes, M.T.; et al. Evaluation of ecosystem dynamics, plant geography and terrestrial carbon cycling in the LPJ dynamic global vegetation model. Glob. Chang. Biol. 2003, 9, 161-185. [CrossRef]

17. Xu-Ri; Prentice, I.C.; Spahni, R.; Niu, H.S. Modelling terrestrial nitrous oxide emissions and implications for climate feedback. New Phytol. 2012, 196, 472-488. [CrossRef] [PubMed]

18. Cheng, L.; Zhang, L.; Wang, Y.-P.; Yu, Q.; Eamus, D. Quantifying the effects of elevated $\mathrm{CO}_{2}$ on water budgets by combining FACE data with an ecohydrological model. Ecohydrology 2014, 7, 1574-1588. [CrossRef]

19. Li, F.Y.; Newton, P.C.D.; Lieffering, M. Testing simulations of intra- and inter-annual variation in the plant production response to elevated $\mathrm{CO} 2$ against measurements from an 11-year FACE experiment on grazed pasture. Glob. Chang. Biol. 2014, 20, 228-239. [CrossRef]

20. De Kauwe, M.G.; Medlyn, B.E.; Zaehle, S.; Walker, A.P.; Dietze, M.C.; Wang, Y.-P.; Luo, Y.; Jain, A.K.; El-Masri, B.; Hickler, T.; et al. Where does the carbon go? A model—Data intercomparison of vegetation carbon allocation and turnover processes at two temperate forest free-air $\mathrm{CO}_{2}$ enrichment sites. New Phytol. 2014, 203, 883-899. [CrossRef]

21. Zaehle, S.; Medlyn, B.E.; De Kauwe, M.G.; Walker, A.P.; Dietze, M.C.; Hickler, T.; Luo, Y.; Wang, Y.-P.; El-Masri, B.; Thornton, P.; et al. Evaluation of 11 terrestrial carbon-nitrogen cycle models against observations from two temperate Free-Air $\mathrm{CO}_{2}$ Enrichment studies. New Phytol. 2014, 202, 803-822. [CrossRef] 
22. Walker, A.P.; Hanson, P.J.; De Kauwe, M.G.; Medlyn, B.E.; Zaehle, S.; Asao, S.; Dietze, M.; Hickler, T.; Huntingford, C.; Iversen, C.M.; et al. Comprehensive ecosystem model-data synthesis using multiple data sets at two temperate forest free-air $\mathrm{CO}_{2}$ enrichment experiments: Model performance at ambient $\mathrm{CO}_{2}$ concentration. J. Geophys. Res. Biogeosci. 2014, 119, 2013JG002553. [CrossRef]

23. Walker, A.P.; Zaehle, S.; Medlyn, B.E.; De Kauwe, M.G.; Asao, S.; Hickler, T.; Parton, W.; Ricciuto, D.M.; Wang, Y.-P.; Wårlind, D.; et al. Predicting long-term carbon sequestration in response to $\mathrm{CO}_{2}$ enrichment: How and why do current ecosystem models differ? Glob. Biogeochem. Cycles 2015, 29, 2014 GB004995. [CrossRef]

24. Houska, T.; Kraft, P.; Liebermann, R.; Klatt, S.; Kraus, D.; Haas, E.; Santabarbara, I.; Kiese, R.; Butterbach-Bahl, K.; Müller, C.; et al. Rejecting hydro-biogeochemical model structures by multi-criteria evaluation. Environ. Model. Softw. 2017, 93, 1-12. [CrossRef]

25. Kellner, J.; Multsch, S.; Houska, T.; Kraft, P.; Müller, C.; Breuer, L. A coupled hydrological-plant growth model for simulating the effect of elevated $\mathrm{CO}_{2}$ on a temperate grassland. Agric. For. Meteorol. 2017, 246, 42-50. [CrossRef]

26. Liebermann, R.; Breuer, L.; Houska, T.; Klatt, S.; Kraus, D.; Haas, E.; Müller, C.; Kraft, P. Closing the N-Budget: How Simulated Groundwater-Borne Nitrate Supply Affects Plant Growth and Greenhouse Gas Emissions on Temperate Grassland. Atmosphere 2018, 9, 407. [CrossRef]

27. Haas, E.; Klatt, S.; Fröhlich, A.; Kraft, P.; Werner, C.; Kiese, R.; Grote, R.; Breuer, L.; Butterbach-Bahl, K. LandscapeDNDC: A process model for simulation of biosphere-atmosphere-hydrosphere exchange processes at site and regional scale. Landsc. Ecol. 2013, 28, 615-636. [CrossRef]

28. Grünhage, L.; Schmitt, J.; Hertstein, U.; Janze, S.; Peter, M.; Jäger, H.-J., III. Beschreibung der Versuchsfläche. In Auswirkungen Dynamischer Veränderungen der Luftzusammensetzung und des Klimas auf Terrestrische Ökosysteme in Hessen-II-Umweltbeobachtungs- und Klimafolgenforschungsstation Linden, Jahresbericht 1995; Schriftenreihe der Hessischen Landesanstalt für Umwelt 220; Umweltplanung, Arbeits- und Umweltschutz: Wiesbaden, Germany, 1996; ISBN 3-89026-236-8.

29. Jäger, H.-J.; Schmidt, S.W.; Kammann, C.; Grünhage, L.; Müller, C.; Hanewald, K. The University of Giessen Free-Air Carbon dioxide Enrichment study: Description of the experimental site and of a new enrichment system. J. Appl. Bot. 2003, 77, 117-127.

30. Patterson, D.E.; Smith, M.W. The use of time domain reflectometry for the measurement of unfrozen water content in frozen soils. Cold Reg. Sci. Technol. 1980, 3, 205-210. [CrossRef]

31. Kammann, C.; Müller, C.; Grünhage, L.; Jäger, H.-J. Elevated $\mathrm{CO}_{2}$ stimulates $\mathrm{N}_{2} \mathrm{O}$ emissions in permanent grassland. Soil Biol. Biochem. 2008, 40, 2194-2205. [CrossRef]

32. Kammann, C.; Grünhage, L.; Jäger, H.-J., II. $\mathrm{N}_{2} \mathrm{O}$ - und $\mathrm{CH}_{4}$-Flüsse in der bodennahen Atmosphäre eines extensiv genutzten Grünlandökosystems. In Auswirkungen Dynamischer Veränderungen der Luftzusammensetzung und des Klimas auf Terrestrische Ökosysteme in Hessen-III-Umweltbeobachtungs- und Klimafolgenforschungsstation Linden, Berichtszeitraum 1996-1999; Schriftenreihe der Hessischen Landesanstalt für Umwelt; Umweltplanung, Arbeits- und Umweltschutz: Wiesbaden, Germany, 2000; Volume 274, ISBN 3-89026-311-9.

33. Grote, R.; Lehmann, E.; Brümmer, C.; Brüggemann, N.; Szarzynski, J.; Kunstmann, H. Modelling and observation of biosphere-atmosphere interactions in natural savannah in Burkina Faso, West Africa. Phys. Chem. Earth Parts ABC 2009, 34, 251-260. [CrossRef]

34. Grote, R.; Lavoir, A.-V.; Rambal, S.; Staudt, M.; Zimmer, I.; Schnitzler, J.-P. Modelling the drought impact on monoterpene fluxes from an evergreen Mediterranean forest canopy. Oecologia 2009, 160, 213-223. [CrossRef] [PubMed]

35. Kraus, D.; Weller, S.; Klatt, S.; Santabárbara, I.; Haas, E.; Wassmann, R.; Werner, C.; Kiese, R.; Butterbach-Bahl, $\mathrm{K}$. How well can we assess impacts of agricultural land management changes on the total greenhouse gas balance $\left(\mathrm{CO}_{2}, \mathrm{CH}_{4}\right.$ and $\left.\mathrm{N}_{2} \mathrm{O}\right)$ of tropical rice-cropping systems with a biogeochemical model? Agric. Ecosyst. Environ. 2016, 224, 104-115. [CrossRef]

36. Farquhar, G.D.; von Caemmerer, S.; Berry, J.A. A biochemical model of photosynthetic $\mathrm{CO}_{2}$ assimilation in leaves of $\mathrm{C}_{3}$ species. Planta 1980, 149, 78-90. [CrossRef] [PubMed]

37. Kraus, D.; Weller, S.; Klatt, S.; Haas, E.; Wassmann, R.; Kiese, R.; Butterbach-Bahl, K. A new LandscapeDNDC biogeochemical module to predict $\mathrm{CH}_{4}$ and $\mathrm{N}_{2} \mathrm{O}$ emissions from lowland rice and upland cropping systems. Plant Soil 2014, 386, 125-149. [CrossRef] 
38. Dirnböck, T.; Kraus, D.; Grote, R.; Klatt, S.; Kobler, J.; Schindlbacher, A.; Seidl, R.; Thom, D.; Kiese, R. Substantial understory contribution to the $\mathrm{C}$ sink of a European temperate mountain forest landscape. Landsc. Ecol. under review.

39. Cukier, R.I.; Fortuin, C.M.; Shuler, K.E.; Petschek, A.G.; Schaibly, J.H. Study of the sensitivity of coupled reaction systems to uncertainties in rate coefficients. I Theory. J. Chem. Phys. 1973, 59, 3873-3878. [CrossRef]

40. Saltelli, A.; Tarantola, S.; Chan, K.P.-S. A Quantitative Model-Independent Method for Global Sensitivity Analysis of Model Output. Technometrics 1999, 41, 39-56. [CrossRef]

41. McKay, M.D.; Beckman, R.J.; Conover, W.J. A Comparison of Three Methods for Selecting Values of Input Variables in the Analysis of Output from a Computer Code. Technometrics 1979, 21, 239-245.

42. Beven, K.; Freer, J. Equifinality, data assimilation, and uncertainty estimation in mechanistic modelling of complex environmental systems using the GLUE methodology. J. Hydrol. 2001, 249, 11-29. [CrossRef]

43. Houska, T.; Kraft, P.; Chamorro-Chavez, A.; Breuer, L. SPOTting Model Parameters Using a Ready-Made Python Package. PLoS ONE 2015, 10, e0145180. [CrossRef]

44. Andresen, L.C.; Yuan, N.; Seibert, R.; Moser, G.; Kammann, C.I.; Luterbacher, J.; Erbs, M.; Müller, C. Biomass responses in a temperate European grassland through 17 years of elevated $\mathrm{CO}_{2}$. Glob. Chang. Biol. 2017, 24, 3875-3885. [CrossRef] [PubMed]

45. Niklaus, P.A.; Spinnler, D.; Körner, C. Soil moisture dynamics of calcareous grassland under elevated $\mathrm{CO}_{2}$. Oecologia 1998, 117, 201-208. [CrossRef] [PubMed]

46. Qi, Z.; Morgan, J.A.; McMaster, G.S.; Ahuja, L.R.; Derner, J.D. Simulating Carbon Dioxide Effects on Range Plant Growth and Water Use with GPFARM-Range Model. Rangel. Ecol. Manag. 2015, 68, 423-431. [CrossRef]

47. Kammann, C. Die Auswirkung Steigender Atmosphärischer $\mathrm{CO}_{2}$-Konzentrationen auf die Flüsse der Klimaspurengase $\mathrm{N}_{2} \mathrm{O}$ und $\mathrm{CH}_{4}$ in Einem Grünland-Ökosystem. Available online: http://geb.uni-giessen. de/geb/volltexte/2001/491/ (accessed on 7 March 2019).

48. Xiang, S.-R.; Doyle, A.; Holden, P.A.; Schimel, J.P. Drying and rewetting effects on C and N mineralization and microbial activity in surface and subsurface California grassland soils. Soil Biol. Biochem. 2008, 40, 2281-2289. [CrossRef]

49. Müller, C.; Stevens, R.J.; Laughlin, R.J.; Jäger, H.-J. Microbial processes and the site of $\mathrm{N}_{2} \mathrm{O}$ production in a temperate grassland soil. Soil Biol. Biochem. 2004, 36, 453-461. [CrossRef]

50. Moser, G.; Gorenflo, A.; Brenzinger, K.; Keidel, L.; Braker, G.; Marhan, S.; Clough, T.J.; Müller, C. Explaining the doubling of $\mathrm{N}_{2} \mathrm{O}$ emissions under elevated $\mathrm{CO}_{2}$ in the Giessen FACE via in-field $15 \mathrm{~N}$ tracing. Glob. Chang. Biol. 2018, 24, 3897-3910. [CrossRef]

51. Kammann, C.; Grünhage, L.; Grüters, U.; Janze, S.; Jäger, H.-J. Response of aboveground grassland biomass and soil moisture to moderate long-term $\mathrm{CO}_{2}$ enrichment. Basic Appl. Ecol. 2005, 6, 351-365. [CrossRef]

52. Denef, K.; Bubenheim, H.; Lenhart, K.; Vermeulen, J.; Van Cleemput, O.; Boeckx, P.; Müller, C. Community shifts and carbon translocation within metabolically-active rhizosphere microorganisms in grasslands under elevated $\mathrm{CO}_{2}$. Biogeosciences 2007, 4, 769-779. [CrossRef]

53. Guenet, B.; Lenhart, K.; Leloup, J.; Giusti-Miller, S.; Pouteau, V.; Mora, P.; Nunan, N.; Abbadie, L. The impact of long-term $\mathrm{CO}_{2}$ enrichment and moisture levels on soil microbial community structure and enzyme activities. Geoderma 2012, 170, 331-336. [CrossRef]

54. Dämmgen, U.; Grünhage, L.; Schaaf, S. The precision and spatial variability of some meteorological parameters needed to determine vertical fluxes of air constituents. Landbauforschung Volkenrode 2005, 55, 29-37.

55. Scholz-Seidel, C.D. UV 2 Messungen der Bulk-Depositionen sedimentierender anorganischer Spezies (September 1993 bis Dezember 1995). In Auswirkungen Dynamischer Veränderungen der Luftzusammensetzung und des Klimas auf Terrestrische Ökosysteme in Hessen-II-Umweltbeobachtungs- und Klimafolgenforschungsstation Linden, Jahresbericht 1995; Schriftenreihe der Hessischen Landesanstalt für Umwelt 220; Umweltplanung, Arbeits- und Umweltschutz: Wiesbaden, Germany, 1996.

(C) 2019 by the authors. Licensee MDPI, Basel, Switzerland. This article is an open access article distributed under the terms and conditions of the Creative Commons Attribution (CC BY) license (http://creativecommons.org/licenses/by/4.0/). 